\title{
カーボンナノファイバー強化プラスチックの機械的特性の評価*
}

\author{
荒 井 政 大*1, 桑 原 敏 和*2, 林 部 真 悟*3 \\ 高 橋 幸 彦*4, 遠 藤 守 信 ${ }^{* 5}$, 杉 本 公一*1
}

\section{Evaluation of Mechanical Property for Carbon Nano-fiber Reinforced Plastics}

\author{
Masahiro ARAI*6, Toshikazu KUWABARA, Shingo HAYASHIBE, \\ Yukihiko TAKAHASHI, Morinobu ENDO and Ko-ichi SUGIMOTO \\ ${ }^{* 6}$ Department of Mechanical Systems Engineering, Shinshu University, \\ 4-17-1 Wakasato, Nagano-shi, Nagano, 380-8553 Japan
}

\begin{abstract}
In the present paper, mechanical properties of the carbon-nano-fiber reinforced plastic are discussed. Two kinds of carbon-nano-fiber are employed for the filler of the composites, namely vapor grown carbon fiber (VGCF) and cups-stacked carbon nanofiber (CNF (CS)). For the matrix of the composites, three kinds of thermoplastic resin are used which are polypropylene (PP), polyamide (PA 12) and poly-ether-ether-ketone (PEEK). 3-point bending test using short beams are executed to obtain the anisotropic properties of the specimens processed by injection molding. Standard tensile tests are executed to evaluate the stress-strain relation, tensile strength and elastic moduli of the composite materials. Furthermore, Mode I fracture toughness of the composite are evaluated using center-notched flexure specimens. These mechanical properties and characteristics for the specimens are compared and discussed in detail, and the fracture aspects are investigated by scanning electron microscope (SEM).
\end{abstract}

Key Words: Carbon Nano-fiber (CNF), Carbon Nano-tube (CNT), Composite Materials, Fracture Toughness, Tensile Test, Injection Molding, Thermoplastic Resin

\section{1. 緒 論}

カーボンナノチューブ (Carbon Nano-tube : CNT) およびカーボンナノファイバー (Carbon Nano-fiber : $\mathrm{CNF})^{(1)(2)(3)(4)(5)}$ は, 従前のピッチ系もしくはPAN 系の炭素織維に比較して, その直径が 1 析以上も小さ いサブミクロンオーダーの炭素繊維であり，近年その 極めて優れた電気伝導性や熱伝導性に対し，急速に注 目が集まっている ${ }^{(6)(7)}$. 具体的には, 走査型プローブ 顕微鏡や蓄電池などといった分野において既にその適 用が進められており，導電性プラスチックとしての利 用法も研究が活発化しつつある ${ }^{(8)(9)}$.

炭素䋞維強化複合材料 (Carbon Fiber Reinforced Plastic：CFRP) ${ }^{(10)(11)(12)}$ は, 比強度・比剛性に優 れた構造材として航空宇宙用構造材, 競技用車両, ス ポーツ用具, 電子機器の筐体等への適用が図られてき た. 一方で, 前述のナノオーダーの炭素織維は，その

\footnotetext{
* 原稿受付 2004 年 2 月 2 日

*1 正員, 信州大学工学部 (380-8553 長野市若里 4-17-1)

*2 信州大学大学院工学系研究科.

*3 信州大学工学部機械システム工学科

*4 日精樹脂工業(株) (-389-0693 長野県埴科郡坂城町南条 2110).

*5 信州大学工学部.

E-mail : arai@ shinshu-u.ac.jp
}

理想強度や剛性が, ピッチ系もしくは PAN 系の緎維 繊維に比べてはるかに高いことから，これまでの炭 素緎維強化複合材料の機械的特性を大幅に改善する 可能性があるものと期待されている。これまでにも， EVA(Ethylene-Vinylacetate copolymer $)^{(8)}$, ポリス チレン(13)(14), PEEK(Poly-ether-ether-ketone) ${ }^{(15)}$ などをマトリクス材とするナノファイバーとの複合体 に関して，機械的特性の評価が試みられている.

しかしながら樹脂系の複合材料は，フィラとマトリ クス樹脂の多種多様な組み合わせが存在すること,さ らには各々の複合材の成形プロセスにおける最適条件 が, フィラとマトリクス樹脂によって大きく異なること などに起因して，その機械的特性を評価したデー夕は, 現状のところ十分に出揃っていないのが現状である.

そこで本研究では, 機械的特性に優れたカーボンナ ノコンポジット複合材料の開発を目的として, 強化フィ ラとして VGCF(Vapor Grown Carbon Nano-fiber) ならびにカップ積層型カーボンナノファイバー (以下, $\mathrm{CNF}(\mathrm{CS}))$ を用いた繊維強化プラスチックを作製し， その評価を行った. マトリクス材には数種類の熱可塑 性樹脂を用い，射出成形法によって供試材を作製した. VGCF は気相法により合成された高結晶性のカーボ 
Table 1 Properties of carbon nano fibers.

\begin{tabular}{lcc}
\hline & VGCF & CNF(CS) \\
\hline \hline Diameter $[\mathrm{nm}]$ & 150 & $60 \sim 80$ \\
\hline Length $[\mu \mathrm{m}]$ & $10 \sim 20$ & - \\
\hline Density $\left[\mathrm{g} / \mathrm{cm}^{3}\right]$ & 2.0 & 2.1 \\
\hline Strength $[\mathrm{GPa}]$ & - & 7.0 \\
\hline
\end{tabular}

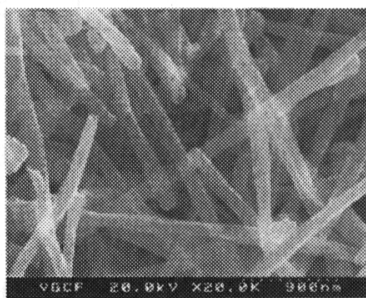

Fig.1 SEM image of vapar grown carbon fiber, VGCF.

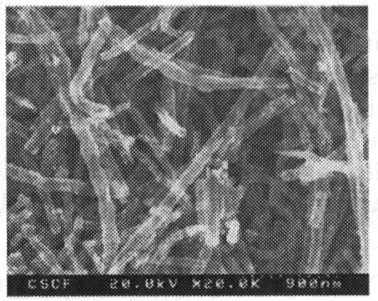

Fig.2 SEM image of cup-stucked carbon-nano fiber, $\mathrm{CS}(\mathrm{CNF})$.

ンナノファイバーであり, 熱伝導性, 導電性, 強度特 性に優れ, 多くのカーボンナノ材料の中でも長い量産 実績を有している。他方, $\mathrm{CNF}(\mathrm{CS})$ は, カップを積 み重ねたような構造を持つカーボンナノファイバーで あり, 複合材のフィラとして用いた場合, その構造的 なメリットを生かして, 樹脂と繊維の接着強度を高め ることができるものと期待されている.

作製された試験片について, 曲げ試験, 引張試験お よびモード I 破壊勒性試験を行い, マトリクス樹脂や フィラの違いによる機械的特性の相違を明らかにする とともに, ナノファイバーの添加量とそれらの機械的 特性の関係について詳細に検討した。 また, コンポジッ 卜材の成形時における射出速度の影響・面内異方性へ の影響に関しても曲げ試験を用いた検討を実施した。

\section{2. 試 験 片}

本論文に用いる供試材はすべて，熱可塑性樹脂にカー ボンナノファイバーを複合させた炭素繊維強化複合材料 である、マトリクス樹脂には汎用結晶性樹脂のポリプロ ピレン (商品名: MA3, 日本ポリケム (株), 以下 PP), ポリアミド 12(3014MX, 北川工業 (株), 以下 PA12), また航空機材料として用いられることの多いポリエー
Table 2 Specification of specimen type.

\begin{tabular}{|l|r|r|}
\hline $\begin{array}{l}\text { Composite } \\
\text { Type }\end{array}$ & $\begin{array}{c}\text { Wf } \\
\text { [wt\%] }\end{array}$ & $\begin{array}{c}\text { Vf } \\
\text { [vol\%] }\end{array}$ \\
\hline PP & 0 & 0 \\
PP/VGCF10 & 10 & 4.8 \\
PP/VGCF20 & 20 & 10.2 \\
PP/VGCF40 & 40 & 23.1 \\
PP/CNF(CS)5 & 5 & 2.2 \\
PP/CNF(CS)10 & 10 & 4.5 \\
\hline PA12 & 0 & 0 \\
PA12/VGCF10 & 10 & 5.3 \\
PA12/VGCF20 & 20 & 11.2 \\
\hline PEEK & 0 & 0 \\
PEEK/VGCF10 & 10 & 6.6 \\
PEEK/VGCF20 & 20 & 13.8 \\
PEEK/VGCF30 & 30 & 21.5 \\
\hline
\end{tabular}

PP : Polypropylene, PA : Polyamide, PEEK : Poly-ether-ether-kethone, Wf : Weight fraction of filler, Vf : Volume fraction of filler

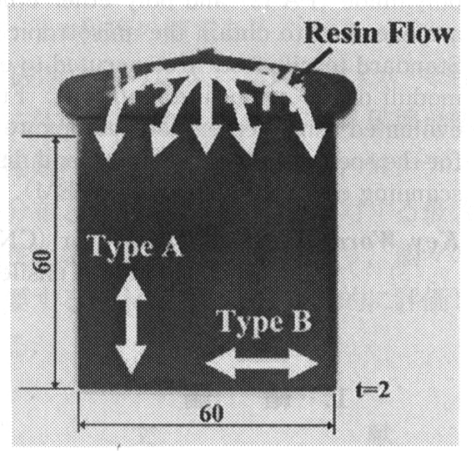

Fig.3 Rectangular sample by injection molding.

テルエーテルケトン $(450 \mathrm{PF}$, ビクトレックス・エム シー (株), 以下 PEEK) を用いた. フィラーには平均 直径 100〜 150 $\mathrm{nm}$ からなる VGCF (昭和電工 (株)) と, 同じく 60〜80nm の直径からなるカップ積層型カーボ ンナノファイバー CNF(CS)(製品名:カルベール 24PS, (株)GSI クレオス) を用いた. $\mathrm{VGCF}$ と CNF(CS) の 基礎デー夕は表 1 に示されるとおりである。 また, 走査 型電子顕微鏡 $(\mathrm{SEM})$ による VGCF および CNF $(\mathrm{CF})$ の観察画像を図 1 と図 2 にそれぞれ示す.

供試材の仕様は, 表 2 に示すとおりである，PP ベー スの複合材についてはVGCF の含有量を変化させた もの 4 種類に加え, カップスタック型炭素繊維を用い たもの 2 種類を, PA12 については VGCF 含有量の異 なるもの 3 種類, PEEK については同様に VGCF 含 有量の異なるもの 4 種類を用いた。 なお, 本研究にお いては,すべて重量混合比 (Wf) を基準として供試材 の作成を行った.

ところで，一般に射出成形を行うにあたっては，樹 


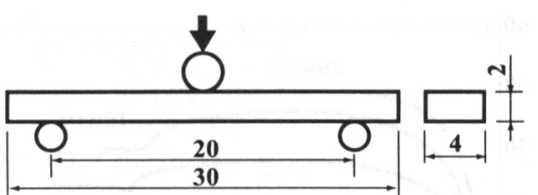

Fig.4 Specimen for bending test.

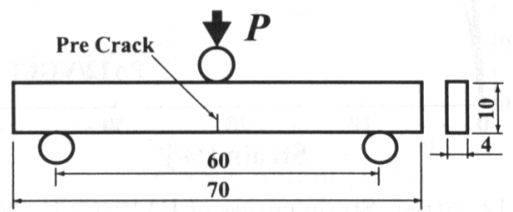

Fig.5 Specimen for mode I fracture touchness test.

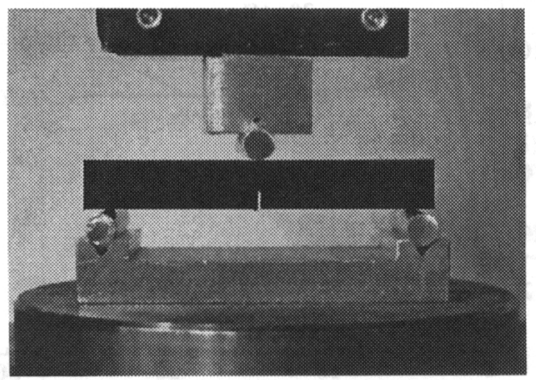

Fig.6 Picture of fracture toughness test equipment.

脂ないし樹脂複合材を米粒よりやや大きな粒状に成形 したペレットと呼ばれる中間成形体を用いる。ペレッ トの作製には，ラボプラストミル $50 \mathrm{MR}$ (東洋精機製 作所), および 2 軸押出機 KZW15-4560MG-SUS-MC （テクノベル）を適宜使用した.

作製されたペレットより，プラスチック射出成形機 PS40-5H (日精樹脂工業) を用いて, 図 3 に示す矩形 のテストピースと, JIS-K-7139 1 号引張試験片を作 製した。

表 2 には参考データとして, 炭素繊維の密度を用いて 計算された体積含有率(Vf)の值も示してある，重量混 合比 $40 \%$ の PP/VGCF40 の実際の密度は $1.14 \mathrm{~g} / \mathrm{cm}^{2}$ であった，樹脂と炭素繊維各々の密度より計算された $\mathrm{PP} / \mathrm{VGCF} 40$ の密度の理論值は $1.15 \mathrm{~g} / \mathrm{cm}^{2}$ であるか ら, 計測値と理論值の差異は極めて小さい. よってボ イド等の混入の少ない試験片が作製されているものと 判断できる.

\section{3. 試 験 方 法}

$3 \cdot 1$ 曲げ試験 本研究では射出成形における 射出速度の影響と，作製された試験片の異方性について 調べるため，曲げ試験を実施した．図 3 に示される矩形 のテストピースを, 図 4 に示される幅 $4 \mathrm{~mm}$, 厚さ $2 \mathrm{~mm}$

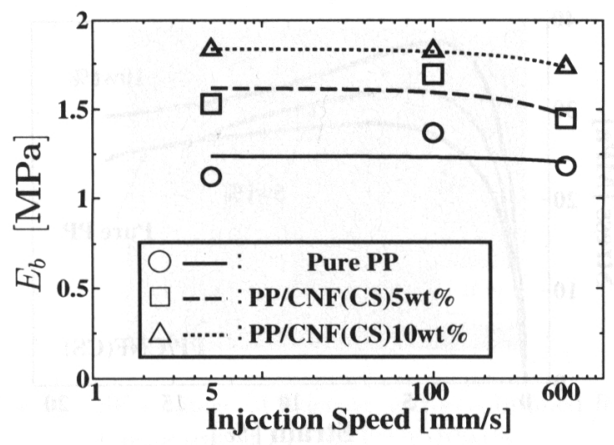

Fig.7 Effect of injection speed on bending modulus of $\mathrm{PP} / \mathrm{CNF}(\mathrm{CS})$.

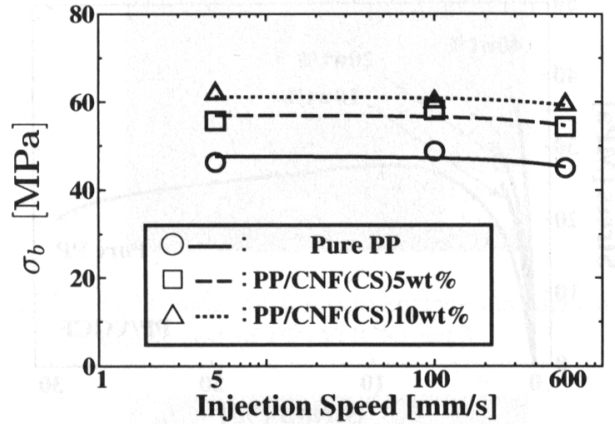

Fig.8 Effect of injection speed on bending strength of $\mathrm{PP} / \mathrm{CNF}(\mathrm{CS})$.

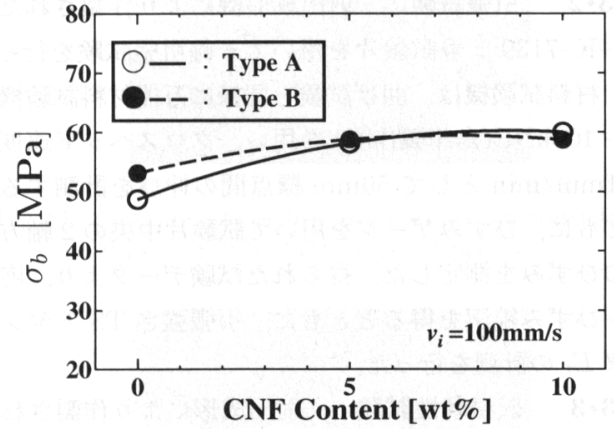

Fig.9 Effect of anisotropy on bending stress of $\mathrm{PP} / \mathrm{CNF}(\mathrm{CS})$.

の短冊状に切り出し, 材料試験機 $\mathrm{AG}-100 \mathrm{kNE}$ (島津 製作所) を用いて 3 点曲げ試験を実施した。試験時の クロスヘッド速度は $1 \mathrm{~mm} / \mathrm{min}$ とし, 種々の射出速度 下において作製された試験片について, 曲げ強度 $\sigma_{b}$ と 曲げ弾性率 $E_{b}$ の測定を行った.

矩形板から短冊状の試験片を切り出す際に, その長 手方向を樹脂の流れ方向としたものを Type A，それ と垂直な方向に切り出したものを Type B とし, 2 種 類の試験片について比較を行った. 


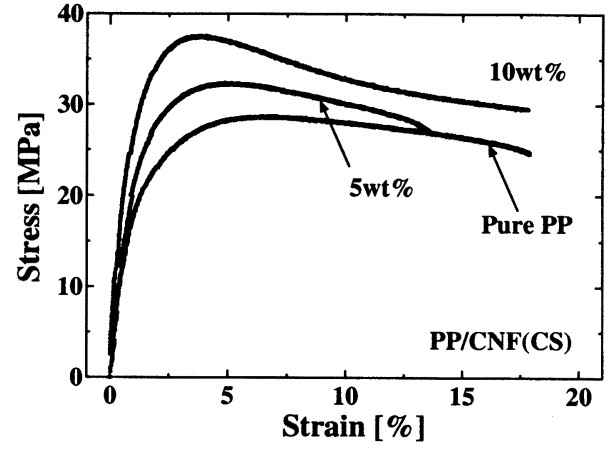

Fig.10 Stress-Strain curves of PP/CNF(CS).

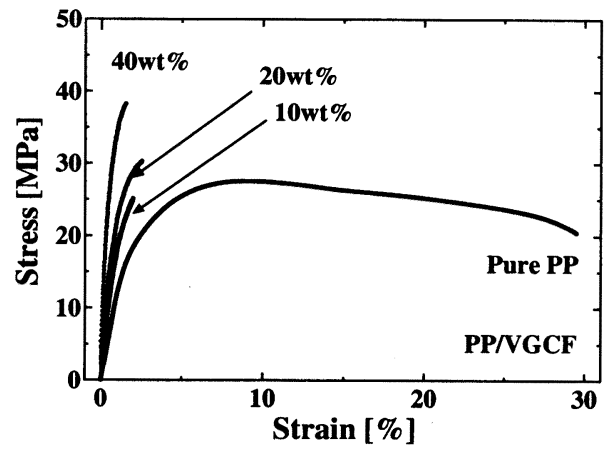

Fig.11 Stress-Strain curves of PP/VGCF.

$3 \cdot 2$ 引張試験 射出成形機により作製された JIS-K-7139 1 号試験片を用いて一軸引張試験を行っ た．材料試験機は，曲げ試験と同様に万能材料試験機 AG-100kNE(島津製作所) を用い, クロスヘッド速度 を $1 \mathrm{~mm} / \mathrm{min}$ として $50 \mathrm{~mm}$ 標点間の伸びを計測する とともに，ひずみゲージを用いて試験片中央の 2 軸方 向のひずみを測定した，得られた試験デー夕より，応 カ一ひずみ線図を得るとともに, 引張強さ TS とヤン グ率 $E_{t}$ の計測を行った.

$\mathbf{3 \cdot 3}$ 破壊勒性試験 射出成形により作製され た JIS-K-7139 1 号試験片の両端を切断することによ り，図 5 に示される破壊勒性試験片を作製した。予き 裂は, ダイヤモンドソーにより幅 $0.8 \mathrm{~mm}$, 長さ $3.5 \mathrm{~mm}$ の切り込みを入れた後, カッター刃を用いてさらにき 裂を $0.5 \mathrm{~mm}$ 程度進展させることにより作製した。

図 6 に示されるように, 3 点曲げ試験を実施するこ とにより，モード I 破壊勒性值の計測を行った。 クロ スヘッド速度 $0.3 \mathrm{~mm} / \mathrm{min}$ で試験片中央部に荷重を加 え, き裂が進展する際の臨界荷重 $P_{c}$ を測定すること によって破壊勒性值 $K_{\mathrm{I} c}$ を決定する，破壞靯性值の算 出にあたっては, 汎用有限要素コード ANSYS を用い て試験片の 2 次元弾性解析を行い, き裂近傍の応力場

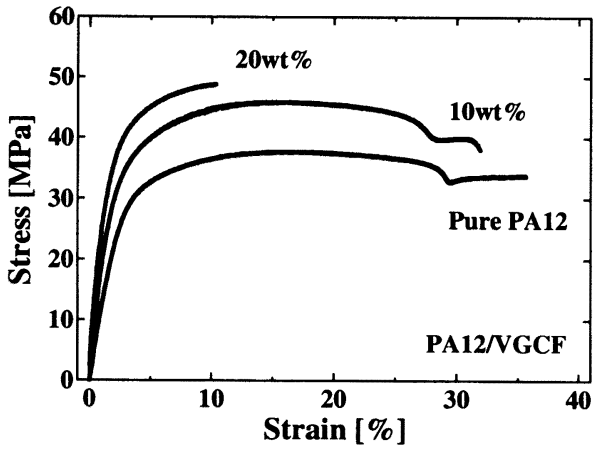

Fig.12 Stress-Strain curves of PA12/CNF(CS).

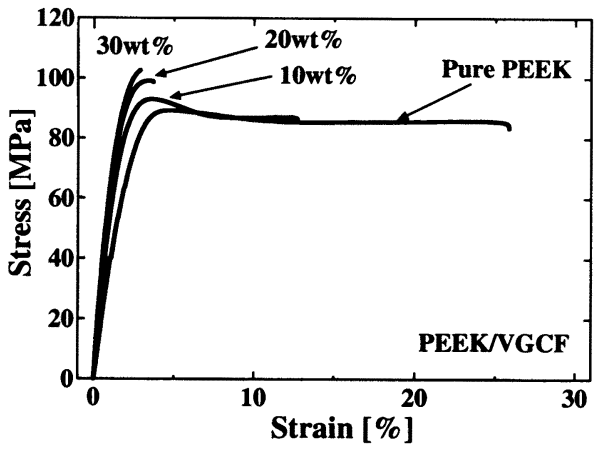

Fig.13 Stress-Strain curves of PEEK/VGCF.

の外挿によって応力拡大係数 $K_{\mathrm{I}}$ を求めた上で破壊勒 性值 $K_{\mathrm{I} c}$ を決定した。

\section{4. 実験結果と考察}

$4 \cdot 1$ 曲げ試験 図 7 および図 8 は, 射出方向 を試験片の長手方向とした Type A 試験片の曲げ強度 $\sigma_{b}$ と曲げ弾性率 $E_{b}$ の試験結果であり, $\mathrm{PP} / \mathrm{CNF}(\mathrm{CS})$ 試験片について射出速度 $v_{i}$ とフィラ添加量の影響をま とめたものである.

この結果から, $\mathrm{PP} / \mathrm{CNF}(\mathrm{CS})$ 複合材料については, フィラ添加量の増加に伴い, $\sigma_{b}$ と $E_{b}$ がともに増加し ていることが確かめられる．曲げ強度については，射 出速度の影敏はさほど見られないものの, ヤング率に 関しては $v_{i}=100 \mathrm{~mm} / \mathrm{s}$ 近傍において值がやや高くな る傾向にあるといえる。

また，図 9 は，同じく $\mathrm{PP} / \mathrm{CNF}(\mathrm{CS})$ 試験片につい て面内異方性の影䇾を示したものである，標準的な射 出速度の $v_{i}=100 \mathrm{~mm} / \mathrm{s}$ の結果を見るかぎり，直交す る 2 方向の曲げ強度に大きな差異は認められず, 試験 片の異方性の程度はそれほど高くないといえる。

曲げ試験の結果を総括すれば, $\mathrm{PP} / \mathrm{CNF}(\mathrm{CS})$ 試験 片における曲げ弾性率, 曲げ強度ともに, 射出速度お 


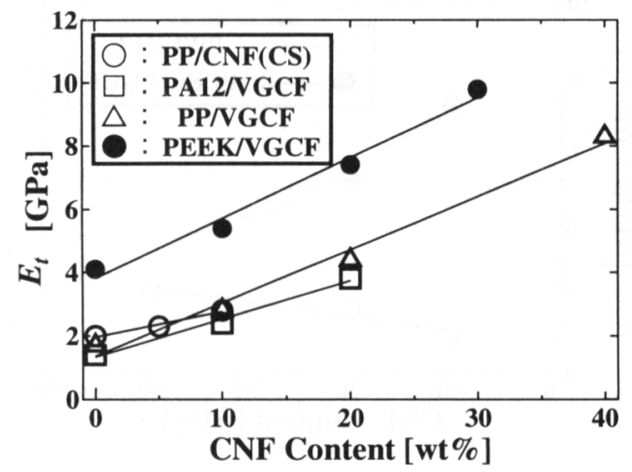

Fig.14 Effect of CNF content on elastic modulus of composites.

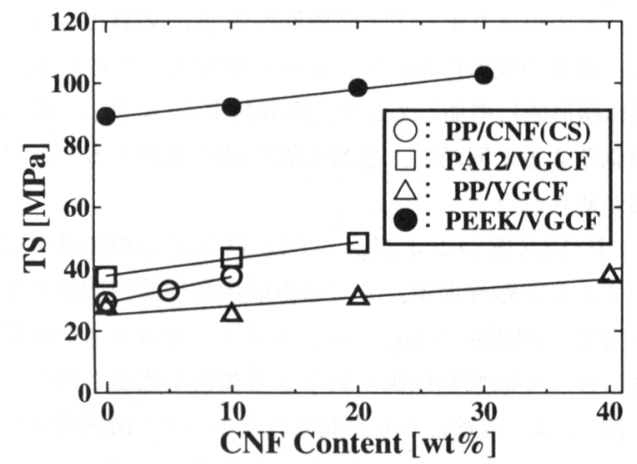

Fig.15 Effect of CNF content on tensile strength of composites.

よび射出方向による材料特性の差異は比較的小さいも のと判断できる.

$4 \cdot 2$ 引張試験 $\mathrm{PP} / \mathrm{CNF}(\mathrm{CS}), \mathrm{PP} / \mathrm{VGCF}$, $\mathrm{PA} 12 / \mathrm{VGCF}$ および PEEK/VGCF の各試験片にお ける応力ーひずみ線図をそれぞれ図 10, 図 11, 図 12, 図 13 に示した。図 11 の PP/VGCF 試験片について みると, フィラを添加した複合材の伸びは小さく, 脆性 的に破断する傾向がみられた，またその傾向は，添加 量の増加とともに顕著となることが確かめられた。 ま た図 13 の PEEK/VGCF 試験片については, フィラ 添加量の增加とともに引張強度は上昇する傾向にある が, 破断伸びは $\mathrm{PP} / \mathrm{VGCF}$ と同様にフィラの増加に よって急激に減少している.

図14，図15 は引張強さ，ヤング率に及ぼすフィラ添 加量の影響をまとめたものである.VGCF. 添加の複合 材についてみると, フィラ添加量の増加に伴うヤング率 ならびに引張強度の増加率 (グラフの傾き) は樹脂の種 類によらずほぼ等しいことがわかる，対して CNF(CS) 複合材に関しては, フィラ添加量に対するヤング率の 増加率は VGCF の場合に比べ低いものの, 引張強度

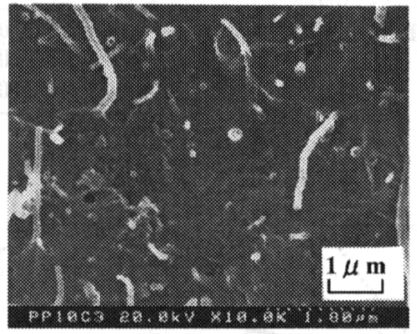

Fig.16 SEM image of fracture surface obtained from tensile test of PP/CNF(CS)10wt\%

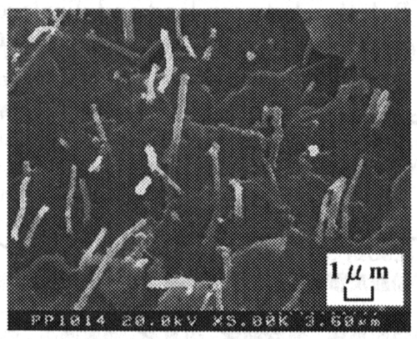

Fig.17 SEM image of fracture surface obtained from tensile test of PP/VGCF10wt\%

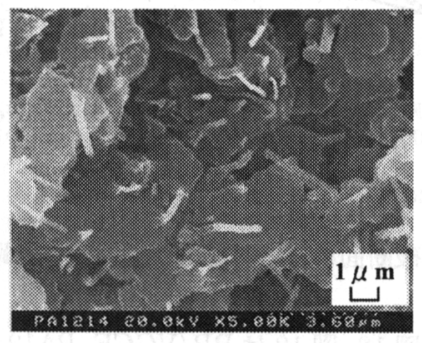

Fig.18 SEM image of fracture surface obtained from tensile test of PA12/VGCF10wt\%

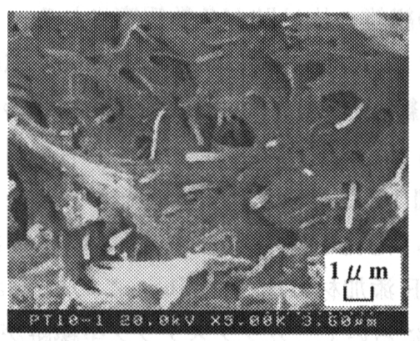

Fig.19 SEM image of fracture surface obtained from tensile test of PEEK/VGCF10wt\%

についてはVGCF の場合よりも高い増加率を示して いることがわかる.

図16 は, PP/CNF(CS) コンポジットに打ける引張 試験後の破面を SEM により観察した画像である。明 


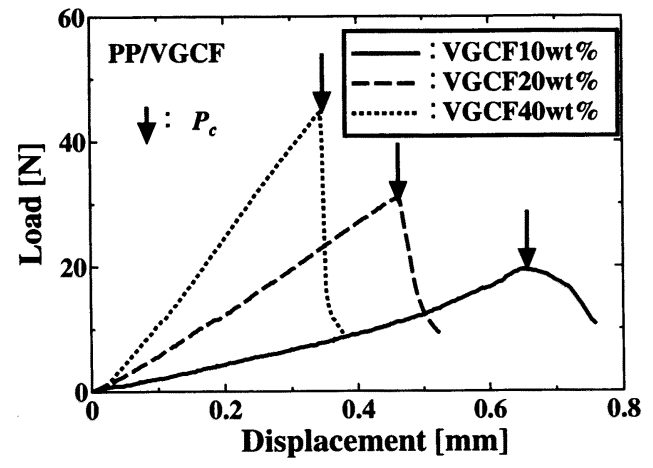

Fig.20 Relation between load and displacement in fracture touchness test of PP/VGCF.

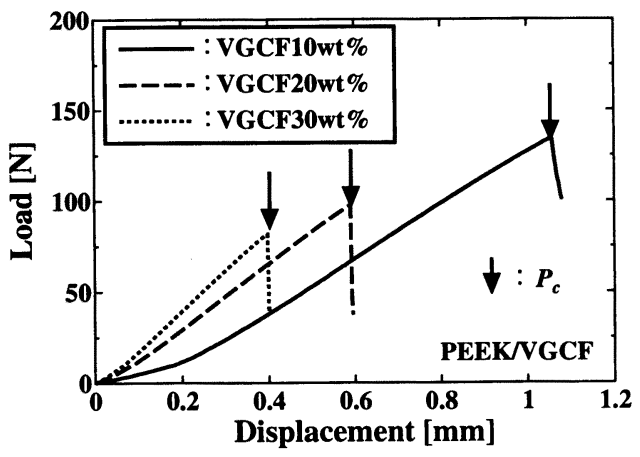

Fig.21 Relation between load and displacement in fracture touchness test of PEEK/VGCF.

らかに, 破断面において瀻維が切断された跡が確認が できる。

図 17, 図 18, 図 19 はPP/VGCF, PA12/VGCF な らびに PEEK/VGCF における破断面の SEM 観察画 像である。これら 3 種類の複合材では, 破断面上に母 材からの瀻維の抜け跡が多数観察される.よって, こ れらのコンポジット材においてより高い強度を実現す るには, 緘維/樹脂界面の強度をさらに高める工夫が必 要であると考えられる.

先の図 13 にも示されているとおり, フィラ含有量 に対する引張強度の增加率は, $\mathrm{CNF}(\mathrm{CS})$ 添加材の方 が VGCF 添加材に比べて高い，この事実は，図 16 の SEM 像において, カップスタック型繊維が切断された と考えられる破面が観察されることと関連性が深いも のと考えられる。

$4 \cdot 3$ 破壊勒性試験 PP/VGCF 試験片および PEEK/VGCF 試験片について，3 点曲げによる破壊 勒性試験を実施した。図 20 , 図 21 は試験により得ら れた荷重と荷重点変位の関係を示している.

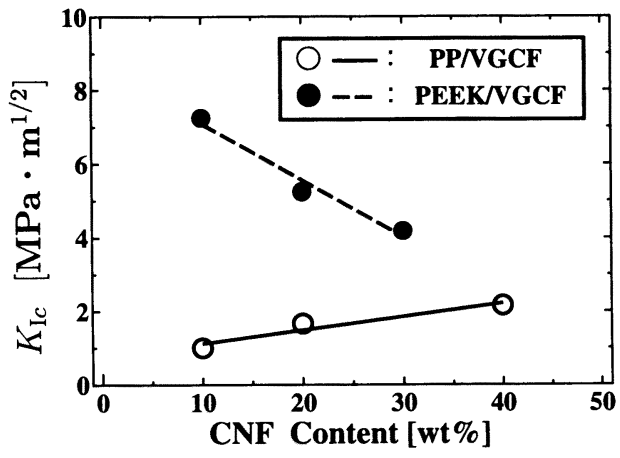

Fig.22 Effect of CNF content on fracture toughness.

本研究では荷重の最も高い値を臨界荷重 $P_{c}$ と定義 し，その值よりモード I 破壞勒性值 $K_{\mathrm{Ic}}$ の算出を行っ た，両者の関係において，変位の増加とともに荷重は 概ね線形的に増加しており, 臨界荷重 $P_{c}$ において荷重 が急落すると同時に, き裂が脆性的に進展することが 確かめられた。

PP/VGCF コンポジットではVGCF の添加量を增 やすことで臨界荷重，すなわち破壊勒性值が增加する 一方で, PEEK/VGCF コンポジットではフィラの增 加に伴って破壊勒性值が低下する傾向が確認された。

図 22 は，実験により計測されたモードI破壊勒性值 $K_{\mathrm{Ic}}$ をまとめたものである.PP/VGCF コンポジットで は, VGCF 添加量にほほ比例した形で破壊勒性值が増 加していることが確かめられる. 他方, PEEK/VGCF 試験片では, フィラ含有量の增加に伴って破壊勒性值が 低下する傾向が確認された，実験後に破断面等の SEM 観察も併せて行ったが，現在のところは破壊勒性值が 低下する明らかな理由は見つかっていない.

本論文で取り扱われた試験片においては，何れの試 験片においても瀻維と樹脂のカップリング処理を施し ていない，一般の炭素瀻維強化複合材のように，瀻維 と樹脂の界面接着強度を增すべく，混練前の炭素瀻維 へのカップリング処理は，所望の機械強度を得るうえ で必須であると考えられる。

引張試験と同様に破壊勒性試験においても，最も物 理特性に優れた PEEK 樹脂コンパウンドにおける試験 結果が，予想に比して好ましくない結果となった．多 くの不満点は, 前述のカップリング処理によってある 程度改善できるものと予想する。

著者らの研究グループでは, シラン溶夜やプラズマ 照射といった前処理を積極的に導入することによって， コンポジット材の機械的性質のさらなる改善を図って ゆく予定である。 


\section{5. 結 論}

本論文では，極微細炭素織維の一種であるカップス タック型カーボンナノファイバー，および多層型気層 合成炭素織維 (VGCF) をフィラとした樹脂複合材料を 作製し， 3 点曲げ試験, 引張試験, モード I 破壞勒性 試験を実施して，その機械的特性について詳細に調査 を行った. 得られた結果を以下に総括する.

(1) $\mathrm{PP} / \mathrm{CNF}(\mathrm{CS})$ コンポジットに対して 3 点曲げ 試験を実施し，曲げ強度と曲げ弾性率を評価し た. フィラ添加量の増加に伴って曲げ応力, 曲 げ弾性率は増加したが，射出速度の影鳘，なら びに射出方向に起因する物性值の異方性は小さ いものと判断された.

(2) $\mathrm{PP} / \mathrm{CNF}(\mathrm{CS}), \mathrm{PP} / \mathrm{VGCF}, \mathrm{PA} 12 / \mathrm{VGCF}$ お よび PEEK/VGCF の 4 種類のコンポジット材 について引張試験を実施した。 どの試験片につ いても, フィラ添加量の増加に伴って引張強度 とヤング率が増加する傾向が確かめられた．な お, VGCF を添加した場合より, $\mathrm{CNF}(\mathrm{CS})$ を 添加した場合の方が引張強度の增加率が高くな る傾向が確認できた.

(3) PP/VGCF 材と PEEK/VGCF 材について, モー ドI 破壊勒性試験を実施した.PP/VGCF 材に 関しては, フィラの添加量を増やすことで破壊 勒性値が大幅に増加した。 他方, PEEK/VGCF
コンポジットでは, フィラの増加に伴い破壊靯性 値が低下する傾向を示すことが明らかとなった。

\section{謝辞}

本研究は, 「文部科学省の指定による長野・上田地域 知的クラスター創成事業」の一環として実施したもの であり，関係者各位に感謝いたします。

\section{文献}

（1）例光ば，斎藤弥八・坂東俊治，カーボンナノチューブの基 礎，コロナ社, (1998).

（2）大竹尚登·槽本和城·安原鋭幸，日本複合材料学会誌，28-6, (2002), 220-227.

（3）小山恒夫·遠藤守信，応用物理，42-7, (1973), 690-696

(4) Iijima, S., Nature, 354, (1991), 56-58.

（5）目崎令司, 炭素, 211, (2004), 30-35.

(6) Gordeyev, S.A., Macedo, F.J., Ferreira, J.A., Hattum,van,F.W.J. and Bernardo,C.A., Physica B, 279 (2000), 33-36.

( 7 ) Patton, R.D., Pittman Jr, C.U., Wang, L., Hill, J.R. and Day, A., Composities (A), 33, (2002), 243-251.

（8）勝亦信・山梨质則 - 牛島均・遠藤守信, 奄気通信学会誌 $(\mathrm{A})$, 113-6, (1993), 473-479.

（9）勝亦信・山梨秀則・牛島均-遠藤守信，電気通信学会誌 (A), 113-9, (1993), 632-637.

(10) 例えは，林狡嗗，愎合材料工学，日科技連，(1980).

(11) 例えは， 北條正樹 - 和郎, 材料, 46-5, (1997), 568-574.

（12）荒井政大 ·立石康博 · 足立忠晴 - 松本浩之, 機論, 64-627, A(1998), 2686-2693.

（13）榎本和城·安原鋭幸·加藤和典·大竹尚登, 機論, 69-680(C), (2003), 309-316.

（14）榎本和城 - 北方傎太郎 - 安原鋭幸・大竹尚登 - 村上碩哉, 精 密工学会秋季大会学術講演会俨演論文集, (2003), 81 .

(15) Sandler, J., Werner, P., Shaffer, M. S. P, Demchuk, V. and Alstadt, V., Composities(A), 33, (2002), 1033-1039. 